\title{
IS GOVERNANCE EFFECTIVE IN ECONOMIC GROWTH? EVIDENCE FROM MSCI COUNTRIES
}

\author{
Hasan ALMOHAMMED

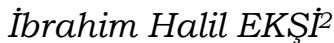

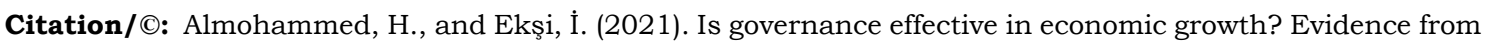
MSCI countries. Hitit Journal of Social Sciences, 14(1), 40-55. doi: 10.17218/hititsbd.926999

Abstract: The main objective of the research is to study the relationship between governance and economic development in emerging economies. We used MSCI countries as a sample due to their increasing importance. Our research is based on the World Bank data for Worldwide Governance Indicators (WGI) of observed countries from 2002 to 2018. The Principal Component Analysis (PCA) and Generalized Method of Moments (GMM) were applied to identify the relationship between the GDP index as a dependent variable and the WGI as an independent variable and other control variables. The experimental results showed that there was no significant relationship between governance and economic development. On the basis of these findings, it is emphasized that the countries in the sample should give more importance to governance.

Keywords: Economic growth, governance, emerging countries, GMM, PCA

\section{Ekonomik Büyümede Yönetişim Etkili Mi? MSCI Ülkelerinden Kanıtlar}

Atıf/(O: Almohammed, H., ve Ekşi, İ. (2021). Ekonomik büyümede yönetişim etkili mi? MSCI ülkelerinin kanıtlar1. Hitit Sosyal Bilimler Dergisi, 14(1), 40-55. doi: 10.17218/hititsbd.926999

Özet: Gelişmekte olan ülkeler yıllık büyümede önemli bir gelişme kaydetmekte ve bugünkü dünya ekonomisinin önemli bir bölümünü oluşturmaktadır (dünya GSYIH'sinin yaklaşık\%60'1). Bu ülkeler dünya nüfusunun\%85'ini temsil ediyor. İlgili nedenlerden dolayı bu ülkelerin ekonomilerinin incelenmesi çok önemli bir konudur. Araştırmanın temel amacı, gelişmekte olan ekonomilerde yönetişim ile ekonomik kalkınma arasındaki ilişkiyi incelemektir. Araştırmamız, 2002'den 2018'e kadar gelişen ekonomilerin Dünya Çapında Yönetişim Göstergeleri (WGI) için Dünya Bankası verilerine dayanmaktadır. Temel Bileşen Analizi (PCA) ve Genelleştirilmiş Momentler Yöntemi (GMM); (GSYH) bir bağımlı değişken, WGI bağımsız bir değişken olarak ve FDI, INF ve WPA göstergeleri birer kontrol değişkenleri olarak uygulanmıştır. Deneysel sonuçlar, yönetişim ve ekonomik kalkınma arasında önemli bir ilişki olmadığını gösterdi. Bu bulgulardan hareketle örneklemdeki ülkelerin yönetişime daha fazla önem vermesi gerektiği vurgulanmaktadır.

Anahtar Kelimeler: Ekonomik büyüme, yönetişim, gelişmekte olan ülkeler, GMM, PCA

\section{INTRODUCTION}

Institutions are a topic that has been increasingly discussed and addressed in recent years, not only in economics, but also in other areas of the social sciences. International organizations and countries use the quality of institutions as a tool to measure and evaluate the economic, social, and political performance of the state (AlBassam, 2013).

Research Article

Submitted: 24.4.202

Accepted: 15.6.2021

*This paper is derived from the master thesis of Hasan ALMOHAMMED "The Effect of Governance on Economic Growth: Evidence From Emerging Countries", Business Administration Department, Gaziantep University, 2021.

1Student, Gaziantep University, Business Administration Department, Gaziantep, Turkey. hasan.fohaiman@gmail.com, http://orcid.org/0000-0003-1591-1256.

2Prof. Dr., Gaziantep University, Economy and Management Faculty, Business Administration Department, Gaziantep, Turkey. ieksi@gantep.edu.tr, http://orcid.org/0000-0002-0239-3253. 
However, economic growth has been, and continues to be, an important goal for countries seeking to promote human and economic development. Moreover, the willingness of governments and international organizations to support economic and human development helps to explain the importance of institutional quality and economic growth (AlBassam, 2013, pp.2-4). For this reason, institutions that lost importance in economic literature since the 1960s have returned to the forefront since the 1990s (Žák and Vymětal, 2005).

Although different definitions are used, the phrase "Emerging Markets" was coined in 1981 by the World Bank economist Antoine Van Agtmael (Techo, 2018) and refers to markets or countries that are less developed than Developed Countries. "Emerging Markets" have some of the characteristics of developed markets, but do not fully meet the latter's standards.

Emerging markets have similar characteristics, such as brisk economic growth and median incomes, (GDP per capita), but are scattered throughout the world in many regions. There are many classifications for emerging markets, but this study relies on the Morgan Stanley Capital International (MSCI) classification (MSCI, 2020), because it is the one most employed in financial studies (Grosse and Meyer, 2018).

These emerging markets are spread across all regions of the world, forming a homogeneous entity with an economy that is responsible for 58\% of the world's total GDP growth (Muller, 2018) and $55 \%$ of the world's total population (The World Bank, 2019). Studies such as those of (Aizpún et al., 2019) and (Grosse and Meyer, 2018), suggest that Emerging Market countries will play the main role in changing the current economic form. Due to this importance, we have selected emerging economies as our sample in this study.

There are many theories of development each one processed the development from a different aspect, and each theory has shortcomings in explaining some of the phenomena in the field of development. Some of these theories are Modernization theory, Dependency theory, World System Theory, Globalization theory, Balanced growth theory, Unbalanced growth theory, Harrod-Domar theory, Unified growth theory, and other theories. This study tends to rely on the new institutional theory because this theory assumes institutions and governance are the main engines for development.

Studies in the literature revealed different results. Some of these have shown a significant relationship between economic growth and governance, while others showed no significant relationship or even no relationship between the two. However, there are no in-depth studies of emerging economies that examine the relationship between governance and economic development in detail. The reason for these differences is from both sample and data set and methodology. Studies have shown that many factors can have an impact on economic growth (population, inflation, foreign aid, education, etc.). This study aims to answer the following questions regarding economic growth and governance:

- Does governance have a significant influence on the economic development of emerging economies?

- Does the influence of governance have a positive or negative impact?

- Are there other factors that can have a significant influence on the economic development of emerging economies?

The answer to these questions has been clarified by examining the relationship between economic development and governance for emerging economies during the long-term period (2002-2018). In addition, in study examined the impact of other control factors that may affect economic growth, such as the working age population (WAP), foreign direct investments (FDI), the impact 
of financial crisis in the years 2008/2009 (DUM), and inflation (INF). The study is based on the MSCI classification in 2020 for emerging economies.

It was noticed that many studies, such as those of (Han et al., 2014; Pere, 2015; Alam et al., 2017; Salawu et al., 2018; Epaphra and Kombe, 2017) have used governance indicators as single indicators. The contribution of this study is to use principal component analysis (PCA) as a method for deriving new variables representing all the six governance indicators, as well as using the generalized method of moments (GMM) to deal with homogeneity and simultaneity biases. In the literature on this topic, one can see studies that use both GMM and PCA, for example, those of (Salawu et al., 2018) and (Emara and Chiu 2016).

In this way, it is aimed to contribute to the regulatory institutions of developing countries. Because knowing the impact of institutionalization on economic growth will motivate regulatory agencies. The economic growth needs of developing countries make it necessary to know the factors that affect their growth, such as institutionalization.

\section{EMERGING ECONOMIES AND GOVERNANCE}

The legislation and governance that control nations have been an integral part of communities since the dawn of civilization. The first written legislation "The Code of Hammurabi" was used in Babylon and dates to about 1754 B.C. Since that time, legislation has evolved, along with developing civilizations, to the advanced and complicated forms of legislation and laws of our time. Today, there is a large amount of specialized legislation and many laws that control the economy, the education system, the health system, security, political life, export and imports, and other aspects of life in every country. The methodology for enacting and monitoring these specialized laws and regulations is called governance.

This advancement in legislation and administrative science has led to the versatile use of the concept of "governance" in every country. Governance now controls all aspects of life in countries, including health, the economy, education, property, the military, elections, etc. Modern studies use indicators to deal with governance, now there are six indicators to meet all dimensions of good legislation; they are Voice and Accountability, Political Stability and Absence of Violence, Government Effectiveness, Regulatory Quality, the Rule of Law, and Control of Corruption (Kaufmann et al., 2008).

The long-term economic efficiency of a country is mainly controlled by legislation and government policies that shape the economic environment in which individuals and firms invest, innovate and transfer ideas, and produce goods and services (Hall and Jones, 1999). Therefore, the relationship between economic development and governance will help explain the factors that influence that efficiency and how it could be improved. For years, international organizations, such as the United Nations, the International Monetary Fund (IMF) and the World Bank have upheld good governance activities as a method for human and economic development (AlBassam, 2013; Santiso, 2001; United Nations, 2007; Mimicopoulos et al., 2007). Governance, therefore, may be seen as one of the most important factors leading to the development and economic growth of a country.

On the other hand, many political and economic studies have posited that institutions are the most important factors, not only for the democratic development of the country, but it is also as one of the prime factors in economic development. Others disagree with this view and argue that this correlation is merely theoretical and that there is insufficient evidence to confirm it (Pere, 2015). 
Economic development is one of the fundamental goals pursued by governments, and it is a goal to which people aspire. This is because it represents the tangible summary of economic and noneconomic efforts in society. It is one of the necessary conditions for improving the standard of living in societies, and an indicator of their prosperity. Economic growth is tied to several basic factors in society that are considered to be the appropriate climate for its development and as factors in the availability of highly skilled institutions, good governance, community participation, scientific research, health, and education. Consequently, the process of achieving an appropriate level of growth is organically linked to the availability of this influential climate. (Khasheeb, 2014)

Economic development is a necessary but not sufficient condition for the improvement of people's material lives. The other condition is the way in which the growth that is achieved is distributed among individuals. This is a delicate issue related to the nature of the economic and political system of each country.

Economic growth is especially important for emerging countries (Khasheeb, 2014). Emerging markets, or emerging economies, have been at the forefront of growth in this century (Muller, 2018). Many emerging markets have exhibited economic development that has exceeded global norms, and others have laid the foundation for growth by establishing economic improvements. Living standards, life expectancy, and individual wealth have increased, although not consistently.

According to (Xu and Meyer, 2012), some of the factors that distinguish emerging economies from developed economies are as follows:

- Markets in Emerging economies are less functional, due to lack of transparency, information asymmetry on a larger scale, and the high cost of supervision and enforcement.

- Governments and government-related agencies not only set the rules but also play an active role in the economy, for example through state-owned or state-controlled enterprises. Network-based behaviors are widespread, partly because of less effective markets, but arguably also because of social mores and their influence on the way that companies interact with each other. Risk and uncertainty are high, due to the volatility of key economic, political, and institutional processes. As a result, it is more difficult for companies to forecast variables, such as business cycles, government actions, and the outcome of legal proceedings, which they need to make strategic decisions. Other negative factors include a lack of efficiency in regulation and the weakness of legal systems.

\section{THEORY AND LITERATURE}

The concept of the new institutional theory concentrates on the effect of the internal institutional environment of states on the process of reforms that they set out. The institutional environment involves some dimensions that interact with each other and seek to regulate the relationships that bind them. The problem of developing countries in achieving development is not only related to setting policies, strategic plans and establishing the physical structure of institutions, but the extent of these countries 'ability to activate these policies, implement strategic plans and properly carry out their institutions. In this context, it is stated that economic performance and its results are linked to formal and informal institutional structures that differ from country to country (Kara and Balid, 2019).

According to this theory, the best model of investigating the governance impact on economic growth is by studying the impact of governance - represented by the WGI variable - on economic growth which is represented by the variable GDP. 
Various studies have investigated the relationship between governance and economic development in many countries around the world (Sub-Saharan Africa, the Balkans, MENA, Thailand, East Asian countries, the European Union, etc.). The studies have included both developed and developing countries. Some have revealed a positive relation between governance and economic development (Han et al., 2014; Alam et al., 2017; Yokoyama, 2011; Salawu et al. 2018; Sen, 2014; Epaphra and Kombe, 2017; Emara and Jhonsa, 2014; Siddiqui and Ahmed, 2009; Siyakiya, 2017; Kraipornsak, 2018), while others have indicated either a negative relation between the two or no relation at all (Emara and Chiu, 2016; Mira and Hammadache, 2017; AlBassam, 2013; Pere, 2015). The Table 1 below summarizes some of the literature.

Table 1. Literature Summary

\begin{tabular}{|c|c|c|c|}
\hline Author/Year & Variables & Methodology & Result \\
\hline $\begin{array}{l}\text { (Siddiqui and } \\
\text { Ahmed, 2009) }\end{array}$ & $\begin{array}{l}\text { GDP - Human Development Indicator - } \\
\text { Inflation - Infrastructure - Savings - } \\
\text { Institutions - International Competitiveness }\end{array}$ & $\begin{array}{l}\text { Generalized } \\
\text { Method of } \\
\text { Moments (GMM) }\end{array}$ & $\begin{array}{l}\text { Significant positive } \\
\text { relationship }\end{array}$ \\
\hline $\begin{array}{l}\text { (AlBassam, } \\
2013)\end{array}$ & $\begin{array}{l}\text { GDP - Governance Variables (6 variables of } \\
\text { WGI) }\end{array}$ & $\begin{array}{l}\text { Generalized } \\
\text { Method of } \\
\text { Moments (GMM) } \\
\end{array}$ & $\begin{array}{l}\text { Significant positive } \\
\text { relationship }\end{array}$ \\
\hline (Sen, 2014) & $\begin{array}{l}\text { Headcount poverty, human development, } \\
\text { gender inequality, literacy, provision of } \\
\text { sanitation, and quality of infrastructure } \\
\text { Control Variables: FDI, Population, number } \\
\text { of } \\
\text { developmental civil society organizations }\end{array}$ & $\begin{array}{l}\text { Ordinary Least } \\
\text { Squares (OLS), }\end{array}$ & $\begin{array}{l}\text { Governance quality } \\
\text { leading to improvements } \\
\text { in the development } \\
\text { indicator. }\end{array}$ \\
\hline $\begin{array}{l}\text { (Han et al., } \\
2014)\end{array}$ & $\begin{array}{l}\text { GDP - Governance Variables - Working-age } \\
\text { population - access to improved water } \\
\text { sources and sanitation- economic } \\
\text { openness- foreign direct investment (FDI) }\end{array}$ & $\begin{array}{l}\text { Panel data (GMM) } \\
\text { and OLS }\end{array}$ & $\begin{array}{l}\text { Significant positive } \\
\text { relationship }\end{array}$ \\
\hline $\begin{array}{l}\text { (Emara and } \\
\text { Jhonsa, 2014) }\end{array}$ & GDP and six Governance Indicators & $\begin{array}{l}\text { Ordinary Least } \\
\text { Squares - Two- } \\
\text { stage Least } \\
\text { Square regression }\end{array}$ & $\begin{array}{l}\text { Significant positive } \\
\text { relationship }\end{array}$ \\
\hline (Pere, 2015) & $\begin{array}{l}\text { GDP - Governance Variables (Government } \\
\text { effectiveness) - ratio of capital formation to } \\
\text { GDP - trade as a percentage of GDP - } \\
\text { Income per capita }\end{array}$ & Panel data & Insignificant relationship \\
\hline $\begin{array}{l}\text { (Emara and } \\
\text { Chiu, 2016) }\end{array}$ & GDP - Governance indicators & $\begin{array}{l}\text { Regression model } \\
\text { and PCA }\end{array}$ & $\begin{array}{l}\text { Significant positive effect } \\
\text { on some countries and } \\
\text { insignificant on some } \\
\text { countries }\end{array}$ \\
\hline $\begin{array}{l}\text { (Siyakiya, } \\
2017)\end{array}$ & $\begin{array}{l}\text { Gross value added per capita - Gross fixed } \\
\text { capital formation - Government } \\
\text { Expenditure - net barter terms of trade } \\
\text { index - institutional quality }\end{array}$ & Panel data & $\begin{array}{l}\text { Significant positive } \\
\text { relationship }\end{array}$ \\
\hline $\begin{array}{l}\text { (Mira and } \\
\text { Hammadache, } \\
\text { 2017) }\end{array}$ & $\begin{array}{l}\text { Five governance indicators: corruption in } \\
\text { the government - State right - the risk of } \\
\text { expropriation - repudiation of } \\
\text { contracts by the government - the quality of } \\
\text { the bureaucracy. } \\
\text { Control variables: Education - log inflation - } \\
\text { Monetary mass / GDP -Export/GDP }\end{array}$ & Panel data & Insignificant relationship \\
\hline $\begin{array}{l}\text { (Alam et al., } \\
2017)\end{array}$ & $\begin{array}{l}\text { GDP - Governance Variables (Government } \\
\text { effectiveness) - the growth of labor force - } \\
\text { primary school enrollment rate - FDI - } \\
\text { Inflation - trade as a percentage of GDP }\end{array}$ & $\begin{array}{l}\text { Generalized } \\
\text { Method of } \\
\text { Moments (GMM) }\end{array}$ & $\begin{array}{l}\text { Significant positive } \\
\text { relationship }\end{array}$ \\
\hline $\begin{array}{l}\text { (Epaphra and } \\
\text { Kombe, 2017) }\end{array}$ & $\begin{array}{l}\text { GDP Growth - Gross fixed capital formation } \\
\text { - Degree of trade openness - Inflation - } \\
\text { Population growth - FDI - } 6 \text { Governance } \\
\text { Indicators }\end{array}$ & $\begin{array}{l}\text { GMM and panel } \\
\text { data }\end{array}$ & $\begin{array}{l}\text { Significant positive } \\
\text { relationship }\end{array}$ \\
\hline $\begin{array}{l}\text { (Kraipornsak, } \\
\text { 2018) }\end{array}$ & $\begin{array}{l}\text { GDP - Governance indicators - real per } \\
\text { capita stock }\end{array}$ & Panel data & $\begin{array}{l}\text { Significant positive } \\
\text { relationship }\end{array}$ \\
\hline $\begin{array}{l}\text { (Salawu et al., } \\
\text { 2018) }\end{array}$ & $\begin{array}{l}\text { GDP - Governance Variables (WGI) - } \\
\text { Working-age Population - access to } \\
\text { improved water sources and sanitation- } \\
\text { trade openness- FDI }\end{array}$ & $\begin{array}{l}\text { PCA, Ordinary } \\
\text { Least Square } \\
\text { (OLS) and GMM }\end{array}$ & $\begin{array}{l}\text { Significant positive effect } \\
\text { on some countries (South } \\
\text { Africa and Ghana) and } \\
\text { negative effect on some } \\
\text { countries (Nigeria) }\end{array}$ \\
\hline
\end{tabular}


Owing to the disparity in the results of research on the effect of governance on economic development, this study contributes to enhancing previous studies on the relationship between institutions and the economic development of an economic demographic block that is constituted by emerging market countries.

\section{METHODOLOGY AND RESULTS}

\subsection{Data and Variables}

Countries targeted in this study involve 25 emerging economy countries. We used the Morgan Stanley Capital International (MSCI) classification of June 2020. The countries are: Argentina, Brazil, the Czech Republic, Chile, Colombia, Peru, Egypt, Greece, Hungary, Qatar, China, India, Indonesia, Korea, Malaysia, Mexico, Pakistan, the Philippines, Poland, Russia, South Africa, Saudi Arabia, Thailand, Turkey and the United Arab Emirates. Annual data is from 2002 to 2018. Data obtained from different sources. All data used are below in Table 2:

Table 2. Data Description

\begin{tabular}{|c|c|c|c|c|}
\hline Variable & Symbol & Definition & References & Source \\
\hline $\begin{array}{l}\text { Annual } \\
\text { growth \% of } \\
\text { GDP per } \\
\text { capita }\end{array}$ & GDP & $\begin{array}{l}\text { Annual growth average of GDP at } \\
\text { market prices based on constant } \\
\text { local currency. (percentage) }\end{array}$ & $\begin{array}{l}\text { (Han et al., 2014), (Alam et al., } \\
\text { 2017), (Pere, 2015), (AlBassam, } \\
\text { 2013), (Salawu et al., 2018), } \\
\text { (Sen, 2014), (Mira and } \\
\text { Hammadache, 2017), } \\
\text { (Kraipornsak, 2018), (Emara } \\
\text { and Jhonsa, 2014), (Epaphra } \\
\text { and Kombe, 2017), (Siddiqui } \\
\text { and Ahmed, 2009) }\end{array}$ & $\begin{array}{l}\text { World } \\
\text { Development } \\
\text { Indicators - } \\
\text { World Bank }\end{array}$ \\
\hline $\begin{array}{l}\text { Worldwide } \\
\text { Governance } \\
\text { Indicator }\end{array}$ & WGI & $\begin{array}{l}\text { WGI represent the six Worldwide } \\
\text { Governance Indicators: } \\
\text { Government Effectiveness (GE), } \\
\text { Political Stability and Absence of } \\
\text { Violence/Terrorism (PV), Control } \\
\text { of Corruption (CC), Regulatory } \\
\text { Quality (RQ), Voice and } \\
\text { Accountability (VA), and Rule of } \\
\text { Law (RL). WGI calculated by } \\
\text { using Principal Component } \\
\text { Analysis for the six governance } \\
\text { indicators. }\end{array}$ & $\begin{array}{l}\text { (Han et al., 2014), (Alam et al., } \\
\text { 2017), (Pere, 2015), (AlBassam, } \\
\text { 2013), (Salawu et al., 2018), } \\
\text { (Sen, 2014), (Mira and } \\
\text { Hammadache, 2017), } \\
\text { (Kraipornsak, 2018), (Emara } \\
\text { and Jhonsa, 2014), (Siddiqui } \\
\text { and Ahmed, 2009) }\end{array}$ & World Bank \\
\hline $\begin{array}{l}\text { Working- } \\
\text { Age } \\
\text { Population }\end{array}$ & WAP & $\begin{array}{l}\text { Represented by the percentage of } \\
\text { populations ages between } 15-64 \\
\text { (\% of the total population) } \\
\text { include all inhabitants regardless } \\
\text { of legal status or nationality. }\end{array}$ & $\begin{array}{l}\text { (Han et al., 2014), (Alam et al., } \\
\text { 2017), (Pere, 2015), (AlBassam, } \\
\text { 2013), (Salawu et al., 2018), } \\
\text { (Sen, 2014), (Mira and } \\
\text { Hammadache, 2017), (Epaphra } \\
\text { and Kombe, 2017) }\end{array}$ & $\begin{array}{l}\text { World } \\
\text { Development } \\
\text { Indicators - } \\
\text { OECD }\end{array}$ \\
\hline $\begin{array}{l}\text { Net inflow of } \\
\text { Foreign } \\
\text { Direct } \\
\text { Investment } \\
\text { (\% of GDP) }\end{array}$ & FDI & $\begin{array}{l}\text { The Foreign Direct Investment } \\
\text { (FDI) is the net inflow of } \\
\text { investment to secure a } \\
\text { permanent management interest } \\
\text { (10\% or more of voting stock) in } \\
\text { a firm working in an economy } \\
\text { other than that of the investor. }\end{array}$ & $\begin{array}{l}\text { (Han et al., 2014), (Alam et al., } \\
\text { 2017), (Salawu et al., 2018), } \\
\text { (Sen, 2014), (Mira and } \\
\text { Hammadache, 2017), (Epaphra } \\
\text { and Kombe, 2017) }\end{array}$ & $\begin{array}{l}\text { World } \\
\text { Development } \\
\text { Indicators - } \\
\text { OECD - } \\
\text { INDEC } \\
\text { †Argentina }\end{array}$ \\
\hline $\begin{array}{l}\text { Inflation } \\
\text { (annual } \\
\text { average \%) }\end{array}$ & INF & $\begin{array}{l}\text { Inflation represents the annual } \\
\text { percentage change in the cost to } \\
\text { the average consumer for } \\
\text { obtaining a basket of } \\
\text { commodities (as measured by the } \\
\text { consumer price index) }\end{array}$ & $\begin{array}{l}\text { (Alam et al., 2017), (Mira and } \\
\text { Hammadache, 2017), (Epaphra } \\
\text { and Kombe, 2017), (Siddiqui } \\
\text { and Ahmed, 2009) }\end{array}$ & $\begin{array}{l}\text { World } \\
\text { Development } \\
\text { Indicators - } \\
\text { IMF }\end{array}$ \\
\hline
\end{tabular}

In addition to these variables, we used a dummy for the 2008-2009 global economic crisis. Because the economic growth of countries was affected in different forms especially emerging countries.

†INDEC: The National Institute of Statistics and Censuses, Argentina. 


\subsection{Empirical Model}

In order to establish whether institutional factors affect the economic development of the emerging countries, we applied a generalized method of moments (GMM) on a sample of 25 emerging countries over the 2002-2018 period.

GMM was introduced by Arellano and Bond (1991), and later developed by Arellano and Bovver (1995) also later by Blundell and Bond (1998). We have three reasons for adopting the GMM technique. Firstly, GMM technique controls for heterogeneity bias deal with the confounding effect of inter-temporal dynamic behavior or unobserved individual heterogeneity. Secondly, the longitudinal approach provides additional information and a richer source of variation, due to the pooling of unobserved individual heterogeneity over the time dimension. The degree of freedom increases thereby, and the efficiency of the econometric estimators improves. Thirdly, unlike cross-sectional data and time-series data, panel data could provide good estimates of aggregate dynamic behavior without the need for a long time series (Lee et al.,2019); (Zainal, et al., 2020). The empirical specification is aimed at explaining the determinants of GDP by testing the role of institutional quality. Thus, the empirical model employed in the analysis was as follows:

$G D P_{i, t}=\beta 0+\beta 1 G D P_{i, t-1}+\beta 2 W G I_{i, t}+\beta 3 F D I_{i, t}+\beta 4 W A P_{i, t}+\beta 5 I N F_{i, t}+\beta 6 D U M+\mu_{i}+\varepsilon_{i, t}$

where GDP is the annual percentage of gross domestic product growth per capita; it is a major indicator of the economic growth level of countries. WGI is institutional quality, FDI is foreign direct investment, WAP is the working-age population, INF is inflation and the indexes $i$ and $t$ represent countries and time, respectively. DUM is expressed the 2008-2009 economic crisis. In addition, the specification contains an unobservable country-specific effect $\mu$ and error-term $\varepsilon$.

\subsection{Empirical Results}

First, the descriptive statistics are given in Table 3.

Table 3. Statistical summary of variables

\begin{tabular}{|c|c|c|c|c|c|}
\hline & FDI & GDP & INF & WAP & WGI \\
\hline Mean & 2.972 & 4.304 & 5.227 & 67.791 & -0.019 \\
\hline Median & 2.429 & 4.396 & 3.808 & 66.670 & 0.075 \\
\hline $\operatorname{Max}$ & 54.648 & 26.170 & 44.964 & 86.398 & 2.260 \\
\hline Min & -41.063 & -10.894 & -4.863 & 54.672 & -2.604 \\
\hline Std. Dev. & 5.286 & 3.754 & 5.377 & 5.998 & 0.890 \\
\hline Jargue-Bera & 61823.280 & 483.109 & 4763.251 & 181.343 & 10.300 \\
\hline
\end{tabular}

As can be seen in the Table 3, standard deviation values are not very high. The highest standard deviation value is seen on the WAP variable. The smallest standard deviation value is seen on WGI.

As secondly, correlations of between variables are given in Table 4.

Table 4. Correlations

\begin{tabular}{lrrrrr}
\hline & GDP & WGI & INF & WAP & FDI \\
\hline GDP & 1 & & & & \\
WGI & -0.009 & 1 & & & \\
INF & -0.045 & -0.076 & 1 & & \\
WAP & 0.142 & 0.166 & -0.217 & 1 & 1 \\
FDI & 0.026 & 0.040 & -0.024 & 0.044 & 0.071 \\
DUM & -0.209 & -0.035 & 0.090 & 0.020 & 1 \\
\hline
\end{tabular}


Results in Table 4 reveal no correlation between GDP and WGI. Also, results showed a considerable negative effect for DUM on GDP, and a weak positive correlation between WAP and GDP. This correlation reveals the impact of economic crisis on economic growth.

GMM results to test WGI and the effect of control variables on GDP are shown in Table 5.

Table 5. GMM Results

\begin{tabular}{|c|c|c|c|}
\hline Variable & Coefficient & Std. Error & Prob. \\
\hline $\operatorname{GDP}(-1)$ & 0.338 & 0.092 & $0.000^{*}$ \\
\hline FDI & 0.035 & 0.048 & 0.460 \\
\hline WGI & -0.257 & 0.264 & 0.330 \\
\hline WAP & -0.408 & 0.164 & $0.013^{* *}$ \\
\hline INF & -0.030 & 0.085 & 0.718 \\
\hline DUM & -2.690 & 0.383 & $0.000 *$ \\
\hline \multicolumn{4}{|c|}{ Effects Specification } \\
\hline \multicolumn{4}{|c|}{ Cross-section fixed (first differences) } \\
\hline AR (1) & & & 0.026 \\
\hline AR (2) & & & 0.166 \\
\hline Wald test (x2) & 241.570 & & 0.000 \\
\hline Sargan test (x2) & 20.548 & & 1.000 \\
\hline
\end{tabular}

The consistency of the GMM estimator relies on two specification tests, the Hansen (1982) J test of over-identifying restrictions and a serial correlation test in the disturbances (Arellano and Bond, 1991). Failure to reject the null of the Sargan test would imply that the instruments are valid, and the model is correctly specified. With respect to the serial correlation test, one should reject the null of the absence of the first-order serial correlation (AR1) and not reject the absence of the second-order serial correlation (AR2). Looking at our test results, our results meet the requirements of the analysis. Namely, when viewed from this angle, in terms of serial correlation, it is not seen as problem in between variables. This result is important for confidence in the analyses.

The results also indicate that our model is statistically significant. Looking at the effect of variables, WAP and DUM variables are statistically significant. Both variable's coefficients are negative on GDP. Whereas our WGI variable is not affecting GDP as statistically. Other control variables are found not significant as statistically.

\section{CONCLUSION AND RECOMMENDATIONS}

Governance is a factor that can affect the economic performance of countries. it contributes to growth by influencing transaction costs, channelling economic activities to the right areas, and establishing trust. In explaining the differences in the economic performance of countries, the conditions of the economic environment and the effectiveness of the rules in this environment are questioned. While economic activities are taking place, the effectiveness of the rules that set these activities to certain standards called governance are expressed as institutional quality and can be the provider of economic growth. However, the improvement in institutional quality can be the provider of economic growth, economic growth can also increase institutional quality through the effect of feedback.

In this study, which was conducted to test whether institutionalization influences economic development in emerging countries, countries in the MSCI classification are included in the analysis. According to the analysis results, it was observed that the variable whose effect was tested, (WGI), did not affect economic growth. This result consistent with works of (Emara and Chiu, 2016; Mira and Hammadache, 2017; AlBassam, 2013; Pere, 2015; Kurtz and Schrank, 
2007) which confirmed no (or weak) relation between governance and economic growth. This finding can be explained by (Mira and Hammadache, 2017) good governance is relevant only if countries reach an adequate level of economic and social development that enable institutions of good governance to boost growth. It can also be explained by (Pere, 2015) that the relation between governance and economic growth cannot be clearly demonstrated only if it studied in the long term.

The findings confirm (Khan, 2007) criticism of the relationship between good governance and economic growth to the extent that our empirical findings do not support the critical importance of the correlation in emerging markets. Therefore, economic growth in emerging market countries can not only be explained by good governance indicators as the institutional theory discussed. The result considers the complexity of issues, including the economic rents that seek in the relationships between political power and coalitions. And to have a clear role of governance on economic growth need to have deep a broader analysis in emerging markets. In other words, the insignificance of the governance variable was interpreted as an indication that the countries within the scope of the analysis could not benefit from the positive effects of institutionalization and should develop themselves in this direction. Despite the positive effects of governance were observed in most of the studies reviewed in the literature, based on these results, we could not confirm the hypothesis we tested.

The effect of DUM variable on economic growth (-2.69) was negative and significant, which mean the high effect of the financial crisis during 2008/2009. This clear effect consistent with IMF reports which revealed the impact of financial crisis on emerging market countries and developed countries, where the annual GDP growth in emerging countries dropped from $8 \%$ to $3 \%$ and in developed countries dropped from $3 \%$ to $-3 \%$ in 2009 . Also, results of study reveal a considerable negative impact of WAP variable on economic growth (-0.41) which explained by (Techo, 2018) that the labor in emerging market countries have less productivity level than the productivity level in the developed countries.

Other control variables FDI and INF were not having considerable impact on economic growth. Result of FDI variable consistent with (Agbloyor et al., 2016) which confirmed there is no impact for FDI on economic growth, and result of INF variable consistent with (Ha et al.,2019) works which confirmed that emerging markets have experienced an extraordinary decline in inflation, inflation in these countries declined to 3.5 percent in 2017 . And many emerging markets achieved stability-oriented and resilient monetary policies.

Based on these results, the study recommends the following:

Governments of emerging countries should pay more attention and give more priorities for governance, by issuing policies and procedures that keep the high level of economic growth and avoid fluctuations in the inflation rate. It should be remembered, however, that governance is a long-term phenomenon and that it has a socio-cultural dimension. Also, governments are recommended to impose more control on financial institutions to ensure transparency and avoid any future financial crises. The final recommendation for emerging markets government to invest in the human capital by improving the quality of formal education and by specialized training and informal education. Emerging markets countries have wide younger population segments, which form a big advantage for these countries if it has been invested.

The findings of our study should be evaluated with an awareness of their limitations. The most important of these constraints are those related to samples and data sets. In future studies, it will be possible to test different control variables with different samples and analyses. 
Peer-review: Externally peer-reviewed.

Conflict of Interest: The authors declare that there is no conflict of interest.

Funding: The authors received no financial support for the research, authorship and/or publication of this article.

Ethical Approval: This article does not contain any studies with human participants or animals performed by the authors.

Author Contributions: Hasan Almohammed (50\%), İbrahim Halil Ekşi (50\%)

\section{REFERENCES}

Acemoglu, D., and Robinson, J. (2010). The role of institutions in growth and development. Review of Economics and Institutions, 1(2), 1-21. doi: 10.5202/rei.v1i2.14

Adli, I., and Shakbkb, I. (2016). Good governance and economic growth: an attempt to model the relationship -case of Algeria. Journal of Economic and Financial Research, 3(2), 281-294. Retrieved from: https://www.asjp.cerist.dz/en/article/4734

Agbloyor, E., Gyeke-Dako, A., Kuipo, R., and Abor, J. (2016). Foreign direct investment and economic growth in SSA: the role of institutions. Thunderbird International Business Review, 58(5), 479-497. doi:10.1002/tie.21791

Aizpún, F., Krueger, F., and Puttaiah, M. (2019). Emerging markets: the silver lining amid a challenging outlook. (D. B. Rogers, Dü.) Swiss Re sigma, 1. Retrieved from: https://www.swissre.com/institute/research/sigma-research/

Alam, M., Kitenge, E., and Bedane, B. (2017). Government effectiveness and economic growth. Economics Bulletin, 37(1), 222-227.

AlBassam, B. A. (2013). The relationship between governance and economic growth during times of crisis. European Journal of Sustainable Development, 2(4), 1-18.

Arellano , M., and Bond, S. (1991). Some tests of specification for panel data: Monte Carlo evidence and an application to employment equations. The Review of Economic Studies, 58(2), 277297. doi: $10.2307 / 2297968$

Arellano, Manuel ; Bover, Olympia. (1995, July). Another look at the instrumental variable estimation of error-components models. Journal of Econometrics, 68(1), 29-51. doi:/ 10.1016/0304-4076(94)01642-D

Blundell, R., and Bond, S. (1998). Initial conditions and moment restrictions in dynamic panel data models. Journal of Econometrics, 87(1), 115-143.

Chibba, M. (2009, January). Governance and development.World Economic, 10(2), 79-108. Retrieved from: https://www.researchgate.net/publication/46547326

Emara, N., and Chui, I.-M. (2016). The impact of governance on economic growth: the case of Middle Eastern and North African countries. Topics in Middle Eastern and North African Economies, 18. Retrieved from http://www.luc.edu/orgs/meea/

Emara, N., and Jhonsa, E. (2014). Governance and economic growth: interpretations for MENA countries. Topics in Middle Eastern and African Economies, 16(2), 164-183. Retrieved from: http://www.luc.edu/orgs/meea/

Epaphra, M., and Kombe, A. (2017). Institutions and economic growth in Africa: Evidence from panel estimation. Business and Economic Horizons, 13(5), 570-590. 
European Central Bank. (2010). The growing importance of emerging Economies. Monthly Bulletin.

Fukuyama, F. (2013). What is governance?, Washington: Center for Global Development. Retrieved from: http://www.cgdev.org/content/publications/detail/ 1426906

Grosse, R., and Meyer, K. (2018). Introduction to managing in Emerging Markets. Oxford Handbook of Managing in Emerging Markets (pp. 2-38), New York: Oxford University Press Retrieved from: https://www.researchgate.net/publication/324919342

Ha, J., Kose, M., and Ohnsorge, F. (2019). Understanding inflation in emerging and developing economies. Istanbul: Koç University-TÜSİAD Economic Research Forum.

Hall, R., and Jones, C. (1999). Why do some countries produce so much more output per worker than others?. The Quarterly Journal of Economics, 114(1), 83-116. Retrieved from: http://www.jstor.org/stable/2586948

Han, X., Khan, H., and Zhuang, J. (2014). Do governance indicators explain development performance? A cross-country analysis. ADB Economics Working Paper Series, 417. Retrieved from: http://hdl.handle.net/11540/4213

Hansen, L. (1982). Large sample properties of generalized method of moments estimators. Econometrica, 50(4), 1029-1054. doi:https://doi.org/10.2307/1912775

IMF. (2020, Dec). International Monetary Fund. Retrieved from: https://www.imf.org/external /datamapper/PCPIPCH@WEO/OEMDC/BRA/VEN/SMQ/ARG?year=2020

Kara, S., and Balid, R. (2019). Achieving economic development according to the new institutional theory. Revue d'économie et de statistique appliquée, 14(1), 230-253. Retrieved from: https://www.asjp.cerist.dz/en/article/36925

Kaufmann, D., Kraay, A., and Mastruzzi, M. (2008). Governance Matters VII : Aggregate and Individual Governance Indicators 1996-2007. Policy Research Working Paper No. 4654, World Bank.

Kaufmann, D. (2005). 10 Myths about governance and corruption. Finance and Development: A quarterly magazine of the IMF, 42(3), 41-43.

K Kaufmann, D., Kraay, A., and Mastruzzi, M. (2010). The worldwide governance indicators: methodology and analytical issues. Policy Research Working Paper, World Bank.

Khan, M. H. (2007). Governance, economic growth and development since the 1960s. Economic and Social Affairs, 54, 1-24.

Khasheeb, J. (2014). Economic growth: concepts and theories. n.y.

Knack, S. K. (1995). Institutions and economic performance: Cross-country tests using alternative institutional measures. Economics and Politics., 7(3), 207-227.

Kraay, D. K. (2007). Governance indicators: Where are we, where should we be going?. World Bank Institute, Development Research Group. The World Bank. doi: 10.1596/1813-9450-4370

Kaufmann, D., and Kraay, A. ( (2003). Governance and growth: Causality which way? Evidence for the World, in brief. World Bank. 
Kraipornsak, P. (2018). Good governance and economic growth:An investigation of Thailand and selected Asian countries. Eurasian Journal of Economics and Finance, 6(1), 93-106. doi:10.15604/ejef.2018.06.01.009

Kurtz, M., and Schrank, A. (2007). Growth and governance: models, measures, and mechanisms. Journal of Politics, 69(2), 538-554. doi:10.1111/j.14682508.2007.00549.x

Lee, Y., Haji Yahya, M., Habibullah, M., and Mohd Ashhari, Z. (2019). Non-performing loans in European Union: country governance dimensions. Journal of Financial Economic Policy, 12(2), 209-226. doi:10.1108/JFEP-01-2019-0027

Masoud R. M., and Kaliappan S., R. (2014). Impact of foreign Aid and foreign direct investment on economic growth: evidence from Sub-Saharan African countries. Journal of Economy Malaysia, 1, 63-73.

Mehanna, R. Y. (2010). Governance and economic development in MENA countries: Does oil affect the presence of a virtuous circle?. Journal of Transnational Management, 15(2), 117-150.

Mimicopoulos, M., Kyj, L., and Sormani, N. (2007). Public governance indicators: a literature review. New York: United Nations publications.

Mira, R., and Hammadache, A. (2017). Good governance and economic growth: A contribution to the institutional debate about state failure in Middle East and North Africa. Asian Journal of Middle Eastern and Islamic Studies, 11(3), 107-120. doi:10.1080/25765949.2017. 12023313

MSCI. (2019, June). MSCI country classification standard. Retrieved from: https:/ / www.msci.com/documents / 1296102/1330218/MSCI-Country-ClassificationStandard-cfs-en.pdf/959ca805-4e33-95a4-1aad-b953688db19d?t=1562142713120

MSCI. (2020, June). MSCI global market accessibility review. Retrieved from MSCI: https://www.msci.com/documents /1296102/1330218/MSCI_2020_Global_Market_Acce ssibility_Review_Report.pdf/78a73a91-af3d-cf21-94e8-1cc2c159d2ce

Muller, D. (2018). Emerging markets - Powerhouse of global growth. Market Commentary, May.

Mustafa, A., and Saneea, A. (2014). Studies in economic development. Beirut: Hasan modern library.

OECD. (2020, Dec 3). OECD Data. doi:10.1787/d339918b-en

Pere, E. (2015, June). The impact of good governance in the economic development of Western Balkan countries. European Journal of Government and Economics, 4(1), 25-45.

Robinson, D. A. (2010). The role of institutions in growth and development. Review of Economics and Institutions, 1(2). doi:10.5202/rei.v1i2.1

Romer, P. M. (1989). Human capital and growth: Theory and evidence. NBER Working Paper No. 3173.

Salawu, M., Yusuff, A., Salman, K., Ogunniyi, A., and Rufa, A. (2018). Does governance influence economic growth in Sub-Saharan Africa?. Global Journal of Human-Social Science: Economics, 18(1).

Santiso,, C. (2001). Good governance and aid effectiveness: World Bank and conditionality. The Georgetown Public Policy Review, 7(1), 1-22. 
Sen, K. (2014). Governance and development outcomes in Asia. In Governance in developing Asia. Edward Elgar Publishing.

Siddiqui, D., and Ahmed, Q. (2009). Institutions and economic growth: A cross country evidence. MPRA. January 8, 2010. Retrieved from: https://mpra.ub.uni-muenchen.de/19747/

Siyakiya, P. (2017). The impact of institutional quality on economic performance: An empirical study of European Union 28 and prospective member countries. World Journal of Applied Economics, 2, 3-24. doi:10.22440/wjae.3.2.1

Techo, V. (2018). Introduction to international emerging markets. Paris: Horizons University. doi:10.13140/RG.2.2.18491.72482

The World Bank. (2019). Data, Population. The World Bank. Retrieved from: https://data.worldbank.org/indicator/SP.POP.TOTL

United Nations. (2007). Good governance practices for the protection of human rights. New York: United Nations Press.

Williams, C. a. (2012). Emerging economies after the global financial crisis: the case of Brazil. Northwestern Journal of International Law and Business, 33(1), 81-119. Retrieved from: http://scholarlycommons.law.northwestern.edu/njilb/vol33/iss 1/2

Winkler, A. (1998). Financial development, economic growth and corporate governance. Working Paper Series: Finance and Accounting, 12. Frankfurt am Main: Univ., Fachbereich Wirtschaftswiss. Retrieved from: http://nbn-resolving.de/urn:nbn:de:hebis:30-18582

Worldbank. (2020, Dec). World Development Indicators. The World Bank. Retrieved from: https://databank.worldbank.org/source/world-development-indicators

$\mathrm{Xu}$, D., and Meyer, K. (2012). Linking theory and context:"Strategy research in emerging economies” after Wright et al. (2005). Journal of Management Studies, 50(7), 1322-1346.

Yokoyama, D. S. (2011). The role of good governance in the knowledge-based economic growth of East Asia - A study on Japan, Newly Industrialized Economies, Malaysia and China. Social Systems Studies, 22, 23-49.

Yousef, T. M. (2004). Development, growth and policy reform in the Middle East and North Africa since 1950. Journal of Economic Perspectives, 18(3), 91-116.

Zainal, N., Kamarudin, F., Hook, L., Bakri, M., Sufian, F., and Nassir, A. (2020). Regulation, supervision and social and financial efficiency of microfinance institutions in ASEAN-5 countries. Malaysian Journal of Economic Studies, 57(2), 253-273.

Žák, M., and Vymětal, P. (2005). Evolution of institutions and economic performance. University of Economics and Management, Centre for Economic Studies. 


\section{GENIŞLETİLMIŞ ÖZET}

\section{Giriş}

Kurumlar ve kurumsallaşma, sadece ekonomide değil, sosyal bilimlerin diğer alanlarında da son yıllarda giderek daha fazla tartışılan ve ele alınan bir konudur. Ülkelerin kurumsallaşmasını açıklamaya çalışan birçok teori söz konusudur. Modernleşme, bağımlılık, dünya sistemi, küreselleşme, dengeli ve dengesiz büyüme teorileri vb gibi birçok teori söz konusudur. Bu çalışma, yeni kurumsal teori çerçevesinde kaleme alınmıştır. Teori, kurumların ve yönetişimin kalkınmanın ana motorları olduğunu varsaymaktadır. Ülkelerin ekonomik performanslarındaki farklılıkların açıklanmasında ekonomik ortamın koşulları ve bu ortamdaki kuralların etkinliği sorgulanmaktadır. Ekonomik faaliyetler gerçekleşirken, bu faaliyetleri yönetişim adı verilen belirli standartlara koyan kuralların etkinliği kurumsal kalite olarak ifade edilmekte ve ekonomik büyümenin sağlayıcısı olabilmektedir.

\section{Araştırma geçmişi}

Konunun önemine dayanarak, dünyanın birçok ülkesinde (Sahra Altı Afrika, Balkanlar, MENA, Doğu Asya ülkeleri, Avrupa Birliği vb.) irdelendiği gözlemlenmiştir. Çalışmalardan bazıları yönetişim ve ekonomik büyüme arasında pozitif bir ilişki olduğunu ortaya koyarken (Han ve diğerleri, 2014; Alam ve diğerleri, 2017; Yokoyama, 2011; Salawu ve diğerleri. 2018; Sen, 2014; Epaphra ve Kombe, 2017; Emara ve Jhonsa, 2014; Siddiqui ve Ahmed, 2009; Siyakiya, 2017; Kraipornsak, 2018); diğerleri ise söz konusu değişkenler arasında olumsuz bir ilişki olduğunu ya da hiç ilişki olmadığını gözlemlemiştir (Emara ve Chiu, 2016; Mira ve Hammadache, 2017; AlBassam, 2013; Pere, 2015). Literatürde kullanılan farklı gelişmişlik sınıflandırmaları söz konusudur. Bu çalışmanın en önemli fark1, örneklem olarak Morgan Stanley Capital International (MSCI)'nın sınıflandırmasına bağlı kalarak farklı bir örneklem kullanması ve farklı bir metodoloji uygulamasidir.

\section{Problem}

Kurumsal kalite - yönetişim ve ekonomik büyüme ile ilgili olarak literatürde yapılan çalışmalarda farklı sonuçlar ortaya çıkmıştır. Bunlardan bazıları ekonomik büyüme ve yönetişim arasında önemli bir ilişki gösterirken, diğerleri iki değişken arasında anlamlı bir ilişki gözlemleyememiştir. $\mathrm{Bu}$ farkl1lıkların nedeni hem örneklemden hem de veri setinden ve metodolojiden kaynaklanmaktadır. Ancak, gelişmekte olan ekonomilere ilişkin yönetişim ve ekonomik büyüme arasındaki ilişkiyi ayrıntılı olarak inceleyen derinlemesine çalışmalar bulunmamaktadır. Araştırmalar, birçok faktörün ekonomik büyüme üzerinde etkili olabileceğini göstermiştir.

\section{Amaç}

Bu makale, GSYİH ile temsil edilen ekonomik büyüme ile dönem boyunca (2002-2018) gelişen piyasa ülkeleri için altı Dünya Çapında Yönetişim Göstergesi tarafından temsil edilen yönetişim arasındaki ilişkiyi incelemeyi amaçlamaktadır. Ayrıca, çalışma çağındaki nüfus, doğrudan yabancı yatırımlar ve Enflasyon gibi ekonomik büyümeyi etkileyebilecek diğer kontrol değişkenlerinin etkisini belirleyin.

\section{Metodoloji}

Endekste yer alan 25 gelişmekte olan ülkenin 2002-2018 periyodundaki yıllık verileri, Dünya Bankasından temin edilmiştir. Bağımlı değişken, yıllık GSYİH büyümeleri; bağımsız değişken ise dünya bankası (WB) tarafından yayınlanan ülkelerin yönetim indeksidir. Çalışabilir ülke nüfusu, net doğrudan yabancı sermaye, enflasyon oranları ve kriz (2008-2009) kukla değişkeni de kontrol değişkenleri olarak modele dâhil edilmiştir. Çalışmada kullanılan ülkelerin kurumsal yönetim endeksleri, yine WB tarafından tespit edilen hükümet etkinliği, siyasi istikrar ve şiddetin/terörizmin yokluğu, yolsuzluğun kontrolü, düzenleyici kalite, seslendirme ve hesap verebilirlik ve hukukun üstünlüğü olmak üzere 6 değişkenden meydana gelmektedir. Söz konusu 6 yönetişim göstergesi, tek tek modellenmek yerine Temel Bileşenler Analizi (PCA) kullanılarak tek skor haline dönüştürülmüştür. Ülkelerin kurumsal yönetişim skorlarının ekonomik büyüme 
üzerindeki etkisini test etmek için Dinamik Panel Veri (GMM) tekniği tercih edilmiştir. Teknik, hem ülke $(\mathrm{N})$ boyutunun zaman $(\mathrm{T})$ boyutundan fazla olması ve içsellik problemleri nedeni ile seçilmiştir.

\section{Bulgular}

Analiz sonuçları, oluşturulan modelin istatistiksel olarak anlamlı olduğunu göstermektedir. Değişkenlerin etkisine bakıldığında, kurumsal yönetim değişkeninin katsayısı anlamlı olarak gözlemlenememiştir. Genç nüfus ve kriz kukla değişkenleri istatistiksel olarak anlamlıdır. Her iki değişkenin katsayıları GSYİH üzerinde negatiftir. Diğer kontrol değişkenleri istatistiksel olarak anlamlı bulunmamıştır.

\section{Sonuç}

Çalışmanın sonucu, yönetişim ve ekonomik büyüme arasında ilişki olmadığını veya zayıf ilişki olduğu doğrulayan bazı çalışmalarla (Emara ve Chiu, 2016; Mira ve Hammadache, 2017; AlBassam, 2013; Pere, 2015; Kurtz ve Schrank, 2007) örtüşmektedir. Bu bulgu, Mira ve Hammadache, 2017 tarafından ortaya konulan "iyi yönetişimin, ancak ülkelerin yeterli bir ekonomik ve sosyal gelişme düzeyine ulaşmaları durumunda geçerlidir” tezi ile beraber değerlendirilmelidir. Yönetişim değişkeninin anlamsız olması, analiz kapsamındaki ülkelerin kurumsallaşmanın olumlu etkilerinden yararlanamadıklarını ve kendilerini bu yönde geliştirmeleri gerektiğinin bir göstergesi olarak yorumlanmıştır. Gelişmekte olan ülkelerin hükümetleri, yönetişime daha fazla dikkat etmeli ve daha fazla öncelik vermelidir. Ancak yönetişimin uzun vadeli bir olgu olduğu ve sosyo-kültürel bir boyutu olduğu unutulmamalıdır. Ayrıca, şeffaflı̆̆ı sağlamak ve gelecekteki mali krizleri önlemek için hükümetlere finansal kurumlar üzerinde daha fazla kontrol uygulaması tavsiye edilmektedir.

Çalışmamızın bulguları, sınırlılıkları ile birlikte değerlendirilmelidir. Bu kısıtların en önemlileri örneklem ve veri setleri ile ilgili olanlardır. İleride yapılacak çalışmalarda farklı kontrol değişkenlerinin farklı örneklem ve analizlerle test edilmesi mümkün olacaktır. 